\title{
FUTUREVOLC: A EUROPEAN VOLCANOLOGICAL SUPERSITE OBSERVATORY IN ICELAND, A MONITORING SYSTEM AND NETWORK FOR THE FUTURE
}

Colm Jordan(1*), Freysteinn Sigmundsson (2), Kristin Vogfjord (3), Magnus T. Gudmundsson (2), Ingvar Kristinsson (3), Sue Loughlin (1), Evgenia Ilyinskaya (1), Andy Hooper (4), Arve Kylling (5), Claire Witham (6), Chris Bean (7), Aoife Braiden (7), Maurizio Ripepe (8), Fred Prata (9), and other members of the FUTUREVOLC team (10)

(1) British Geological Survey, UK (2) Nordic Volcanological Center, Institute of Earth Sciences, University of Iceland (fs@hi.is), (3) Icelandic Meteorological Office, Iceland, (4) Delft University of Technology, Netherlands, (5) Norwegian Institute for Air Research, Norway, (6) UK Met Office, (7) University College Dublin, Ireland, (8) University of Florence, Italy, (9) Nicarnica Aviation, Norway,

(10) FUTUREVOLC Consortium, EC FP7 project

*Email: cji@bgs.ac.uk

\begin{abstract}
FUTUREVOLC is a collaborative project funded through the FP7 Environment Supersite Concept call encompassing 26 partners in 10 countries. The main objectives of FUTUREVOLC are to establish an integrated volcanological monitoring procedure through European collaboration, develop new methods to evaluate volcanic crises, increase scientific understanding of magmatic processes and improve delivery of relevant information to civil protection and authorities. FUTUREVOLC is in the first of its 3.5 year duration, therefore this paper presents aims and expectations rather than results.
\end{abstract}

\section{INTRODUCTION}

Volcanic eruptions occur in Iceland about once every 2-5 years. These eruptions range from being relatively small, posing limited local hazard, to major explosive eruptions and flood basalt outpourings of lava that can have catastrophic effect sin Iceland and serious impacts on Europe and beyond. Approximately $80 \%$ of all Icelandic eruptions are explosive, producing plumes that transport volcanic ash and gas considerable distances [1]. Even small to moderate magnitude eruptions can be serious, posing a risk to air traffic, as exemplified by the
Eyjafjallajökull 2010 eruption. The 39 day event disabled 313 European airports, cancelling over 100,000 flights and disrupting the travel of more than 10 million passengers [2] and causing financial damage estimated up to US\$5 billion [3]. Serious as these losses are, the impact of much larger events, similar to the Laki eruption 1783-4 that lasted for eight months, would be much more severe.

The great variety of styles of volcanic activity demonstrated in Iceland through historic time is unique in Europe [1] and provides FUTUREVOLC with a natural laboratory setting and a potential to advance understanding and modelling of a variety of magmatic and volcanic processes.

\section{METHODOLOGY}

The study area covers all of the volcanic zones of Iceland, with special focus on the most active volcanoes in the Eastern Volcanic Zone including Katla, Grímsvötn, Hekla and Bárðarbunga that are responsible for more than half of all eruptions in Iceland (Figure 1). The project will develop much-needed in-situ sensors and early warning instrumentation allied to airborne and spaceborne remote sensing. 
We will explicitly encourage interaction and knowledge exchange between different scientific disciplines, in particular between solid earth and atmospheric science, and between social and physical sciences. All of the data gathered in the project will be made available through an open-access policy, in particular to facilitate the development of European space services (GEOSS).

The project combines broad European expertise in remote sensing, seismology, volcano deformation, volcanic gas and geochemistry, infrasound, eruption monitoring, physical volcanology, satellite studies of plumes, meteorology, ash dispersal forecasting, and civil defence.

This European consortium leads the way for multi-national volcanological collaboration with the aim of mitigating the effects of major eruptions that pose cross-border hazards. Iceland is selected as a laboratory supersite area for demonstration because of (i) the relatively high rate of large eruptions with potential for long ranging effects, and (ii) Iceland's capability to produce the near full spectrum of volcano processes at its many different volcano types (Figure 1).

Based on present monitoring networks and ongoing research, the project will bridge gaps and combine efforts for a coherent close to real-time evaluation of the state of Icelandic volcanoes and their unrest. For example, we will develop a system that can handle high data volumes and automatically produce deformation measurements from SAR data in near-realtime.

The project will provide timely information on magma movements from combined interpretation of earthquake sources relocated in three-dimensional velocity models, magma sources inferred from ground and space geodetic data, and measurements of volcanic volatiles. For better response during eruptions, the project will develop operational models of magma discharge rate, contributing directly to improved forecasts of ash dispersion. They will help to minimise economic disruption on a European scale during eruptions. By integrating a Volcanic Ash Advisory Centre and a civil protection unit into the project, European citizens will benefit directly from the scientific work of FUTUREVOLC.

Continuous monitoring of Icelandic volcanoes available to FUTUREVOLC includes a dense automated digital seismic network, networks of GPS-stations, borehole strain meters, and a smallaperture infrasonic array. Iceland has now two permanent weather radars, that can monitor volcanic plumes [4], and two mobile weather radars have recently been funded by the International Civil Aviation Organization (ICAO). A Lidar (Light Detection And Ranging) has been monitoring ash in the atmosphere in Iceland since May 2011 as a part of a cooperation between the National Centre for Atmospheric Science (NCAS), UK, and the Icelandic Met Office and in relation to the VANAHEIM consortium. Valuable multi-parameter geophysical, geological, geochemical and meteorological data have been collected during eruptions of the last decade that can be used in the FUTUREVOLC project for testing of new algorithms and validation of interpretative techniques.

The 2010 Eyjafjallajökull and 2011 Grímsvötn eruptions provided particularly rare, high resolution data sets on seismicity and ground deformation, near-field video observations of a volcanic plume, near- 


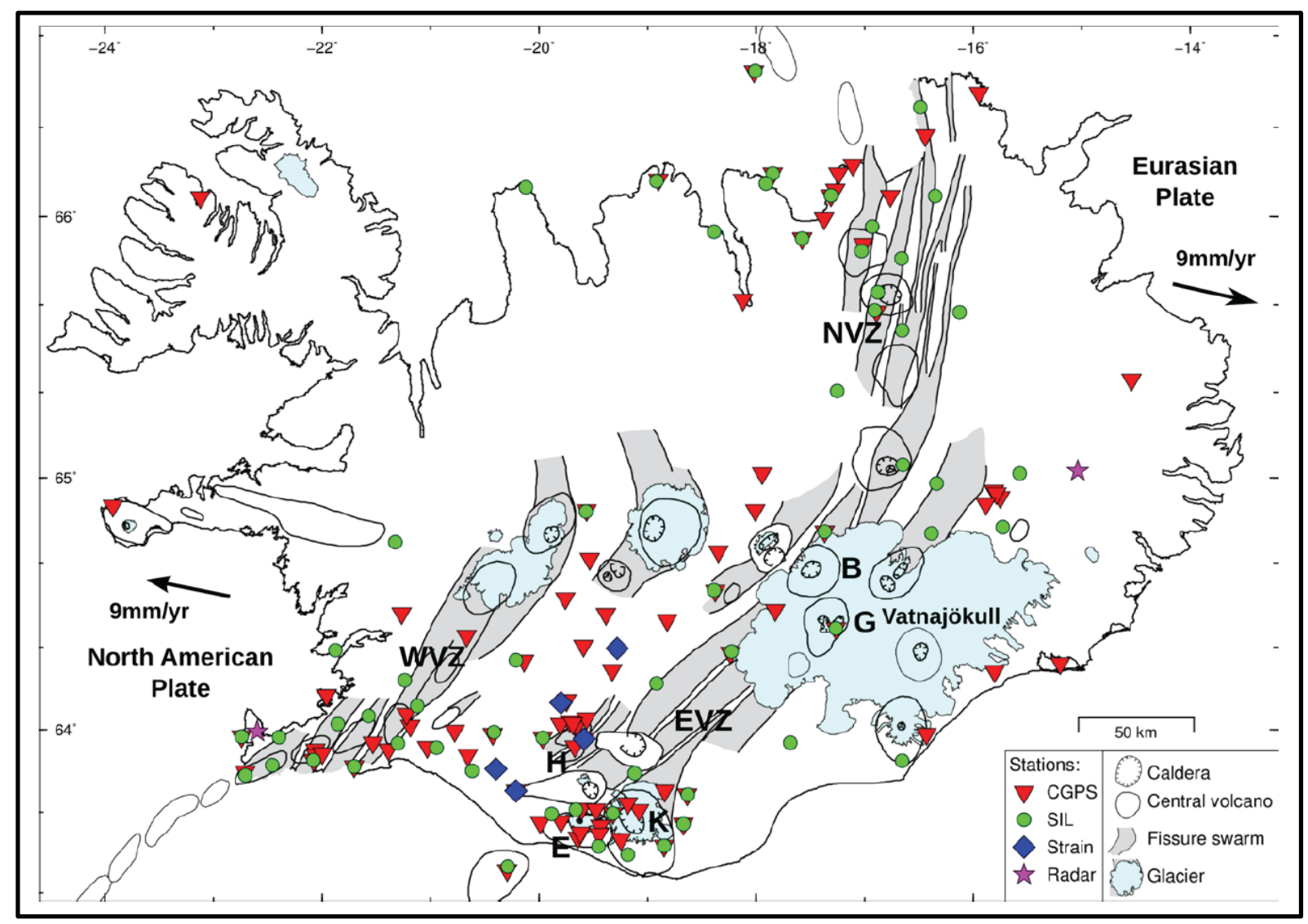

Figure 1. Iceland, volcanoes and present long-term monitoring stations. The volcanic areas consist of volcanic systems, made of central volcanoes, calderas and fissure swarms. Western Eastern, and Northern volcanic zones marked (WVZ, EVZ, NVZ). Iceland's most active volcanoes are Grímsvötn (G) and Bárðarbunga (B) under the Vatnajökull ice cap (V), Katla (K) under Mýrdals-jökull ice cap, and Hekla (H). Eyjafjallajökull vocano is labelled E.

field infrasonic recordings invaluable for the field of volcano-meteorology, aircraft based plume observations and detailed mapping of ash fallout providing quantitative ground truth data for source term model calibrations, Lidar, and remote sensing observations. Gas emission was measured and detailed remote sensing datasets of plume dispersal and transport were obtained for both eruptions.

Space based techniques are extensively used; e.g. with extensive interferometric analysis of synthetic aperture radar (InSAR) images from various satellites, operated by the European, German, Japanese and Canadian space agencies, for deformation monitoring. The consortium includes leading authorities in pushing the limits of this technique [e.g. 5], and the algorithms have played a key role in illuminating magma movements associated with the 2010 Eyjafjallajökull eruption, and many other instances of magmatic migration beneath Icelandic volcanoes. In FUTUREVOLC we will prepare software in advance of the Sentinel-1 launch to take advantage of these data for near real-time monitoring as soon as they come online. When combined with SAR data from the TerraSAR-X and TanDEM-X missions, we will have an unprecedented SAR monitoring capability.

Volcanic ash and gas clouds transported with the prevailing winds were detected and followed day and night by space-based instruments e.g. the Meteosat Second Generation Spin Enhanced Visible and Infrared Imager (MSG-SEVIRI). A combination of satellite data and a Langrangian transport model by an 
inversion scheme allowed the determination of time- and height-resolved volcanic ash emissions. However, an urgent need for measurements of the timevarying vertical source strength has been identified. This may be achieved by nearfield measurement of ash and gas concentrations utilizing multispectral IR cameras allowing the retrieval of ash particle size, mass and optical depth [6].

\section{CONCLUSIONS}

FUTUREVOLC is an ambitious proposal with a team that plans to fully integrate in a seamless manner the tracking of magma from the initial onset of movement at depth in the crust, to modelling, forecasting and monitoring ash fall, thousands of kilometres from the volcano. This ambitious multidisciplinary project requires innovative and cooperative ways of working which will advance understanding and progress the state-ofthe-art in monitoring and understanding of volcanic processes. FUTUREVOLC will be a European and world demonstrator for effective collaborative monitoring and analysis efforts in support of disaster risk reduction for the next decade.

We aim to achieve a paradigm shift in the volcanological community by promoting easy access to data and demonstrating that it works. We believe easy access will promote highly productive and novel research activities, raise awareness of cooperative and collaborative science for the public good at national, regional and international scales and empower the European community to prepare for and respond effectively to volcanic eruptions.

Further information on the project can be found at www.futurevolc.hi.is

\section{ACKNOWLEDGEMENTS}

Funding from the European Union Seventh Framework Programme under grant agreement $308377 \quad$ (Project
FUTUREVOLC) is gratefully acknowledged. This paper is published with the permission of the Executive Director of the British Geological Survey (BGS-NERC).

\section{REFERENCES}

[1] T. Thordarson and G. Larson, Volcanism in Iceland in historic time: Volcano types, eruption styles and eruptive history. Journal of Geodynamics, vol. 43, pp. 118-152. 2007.

[2] D Calleja The EU's response to the ash crisis. Atlantic conference on Eyjafjallajökull \& Aviation, Reykjavik, 15 September 2010. 2011.

[3] Oxford Economics http://www.oxfordeconomics.com/OE_Co ns_Aviation.asp 2010.

[4] P. Arason, A.J. Bennett \& L.E Burgin Charge mechanism of volcanic lightning revealed during the 2010 eruption of Eyjafjallajökull, J. Geophys. Res., vol. 116, B00C03, doi: 10.1029/2011JB008651. 2011.

[5] A. Hooper, D. Bekaert, K. Spaans and M. Arrkan. Recent advances in SAR interferometry time series analysis for measuring crustal deformation, Tectonophysics, 514-517, 1-13, doi:10.1016/j.tecto.2011.10.013. 2012.

[6] A.J. Prata and C. Bernardo. Retrieval of volcanic ash particle size, mass and optical depth from a groundbased thermal infrared camera, J. Volcanology and Geothermal Res. 186, 91-107. 2009. 